\title{
ANALISIS KINERJA PEMERINTAH DAERAH (PEGAWAI PUSKESMAS) DALAM PELAYANAN KESEHATAN MASYARAKAT DI PUSKESMAS MAKBON KECAMATAN MAKBON KABUPATEN SORONG
}

\author{
Ratna Rosmauli Pakpahan, Alfionita Kostantina Su \\ Fakultas Ilmu Sosial Universitas Victory Sorong \\ ratnarosmauli@gmail.com \\ alfionitasu@gmail.com
}

\begin{abstract}
Based on the observations of researchers at the Makbon Public Health Center, Makbon District, Sorong Regency, it was found that the performance of the local government (puskesmas staff) in improving health services to the community was quite good. However, there are still obstacles experienced by Makbon Community Health Center employees in terms of employee housing, and land and sea transportation facilities which must be taken into account by local governments to support the services of puskesmas traveling to the villages (pusling). The method used is a qualitative research method. From the results of the study the researchers concluded that the attention of the local government to the community in health services through Puskesmas employees was still lacking. Therefore, suggestions that can be put forward by researchers in the form of practical advice with more attention to the things that must be done by local governments for health services to the community at the Puskesmas Makbon, Sorong Regency.
\end{abstract}

Keywords: Performance, local government, services, public health, puskesmas

\section{Abstrak}

Berdasarkan hasil pengamatan peneliti pada Puskesmas Makbon Distrik Makbon Kabupaten Sorong diperoleh bahwa kinerja pemerintah daerah (pegawai puskesmas) dalam meningkatkan pelayanan kesehatan kepada masyarakat cukup baik. Namun masih ada kendala-kendala yang dialami oleh pegawai puskesmas makbon dalam hal perumahan pegawai, dan sarana transportasi darat dan laut yang harus di perhatikan lagi oleh pemerintah daerah untuk menunjang pelayanan puskesmas keliling ke kampungkampung (pusling) masih kurang. Metode yang digunakan adalah metode penelitian kualitatif. Dari hasil penelitian peneliti dapat menyimpulkan bahwa perhatian dari pemerintah daerah kepada masyarakat dalam pelayanan kesehatan melalui pegawai puskesmas masih kurang. Saran yang dapat peneliti kemukakan berupa saran praktis dengan lebih memperhatikan hal-hal yang harus dilakukan pemerintah daerah terhadap pelayanan kesehatan kepada masyarakat di Puskesmas Makbon Kabupaten Sorong.

Kata Kunci : kinerja, pemerintah daerah, pelayanan, kesehatan masyarakat, puskesmas

\section{PENDAHULUAN}

Kesehatan adalah keadaan sejahtera dari badan, jiwa, dan sosial yang memungkinkan setiap orang hidup produktif secara sosial, dan ekonomis Undang - Undang Nomor 36 Tahun 2009 Tentang Kesehatan dan sekaligus sebagai investasi, sehingga perlu diupayakan, diperjuangkan dan ditingkatkan oleh setiap individu dan oleh seluruh komponen bangsa, agar 
masyarakat dapat menikmati hidup sehat, dan pada akhirnya dapat mewujudkan derajat kesehatan masyarakat yang optimal. Hal ini perlu dilakukan karena kesehatan bukanlah tanggung jawab pemerintah saja namun merupakan tanggung jawab bersama pemerintah dan masyarakat termasuk swasta.

Empat kesehatan sangat penting bagi masyarakat, ketika seseorang jatuh sakit dan kesulitan untuk menyembuhkan dirinya sendiri dari penyakit atau gangguan kesehatan yang dideritanya, maka mau tidak mau dia harus mencari pertolongan medis agar masalah kesehatan yang dialaminya bisa diatasi secara maksimal. Berikut macam-macam atau jenis-jenis tempat pelayanan kesehatan yaitu : Rumah Sakit, Pusat kesehatan masyarakat (Puskesmas), Puskesmas pembantu (Pustu), Pondok bersalin desa (Polindes) dan lain-lain.

Puskesmas merupakan salah satu bentuk upaya kesehatan bersumber daya masyarakat yang dikelolah dan diselenggarakan dari, oleh, untuk dan bersama masyarakat dalam penyelenggaraan pembangunan kesehatan guna dunia kesehatan di Indonesia saat ini sedang ditimpa kasus-kasus yang tidak menggenakan. Bermula dari kasus gizi buruk, campak dan rumbela di papua, yang hamper setiap hari menghiasi halaman surat kabar, radio, maupun layar televisi. Belum selesai kasus-kasus tersebut, sekarang muncul kasus baru yaitu : pencegahan bulan eliminesi kaki gaja (belkaga) tingkat nasional. Selain itu juga kurangnya pelayanan kesehatan masyarakat. Dewan perwakilan kesehatan (depkes) Republik Indonesia, pedoman umum pengelolaan memberdayakan masyarakat dan memberikan kemudahan kepada masyarakatdalam memperoleh pelayanan kesehatan dasar, utamanya untuk mempercepat angka kematian ibu dan bayi.

Sejak tahun 1979 mulai didirikan pembangunan puskesmas didaerah-daerah tingkat kecamatan, kelurahan atau pedesaan yang memiliki jumlah penduduk 30.000 jiwa, dan untuk mengkordinasi kegiatan-kegiatan yang berada disuatu kecamatan maka salah satu puskesmas tersebut ditunjuk sebagai penanggung jawab yang selanjutnya disebut sebagai pusat kesehatan masyarakat (puskesmas) induk sedangkan yang lain disebut puskesmas pembantu yang dikenal sampai sekarang. Upaya pengembangan SDM (sumber daya manusia) dengan mengoptimalkan potensi pelayanan kesehatan dapat dilaksanakan secara merata apabila sistem pelayanan kesehatan yang berbasis masyarakat seperti puskesmas dapat dilakukan secara efektif dan efisien 
dan dapat menjangkau semua sasaran yang membutuhkanlayanan tumbuh kembang anak, ibu hamil, ibu menyususi, dan nifas (penyembuhan ibu bersalin).

Kondisi ini tidak dibiarkan begitu saja. Oleh karena itu, program revitalisasi puskesmas didaerah, terutama dipedesaan, sudah mendesak dalam upaya peningkatan kualitas kesehatan, pemenuhan kebutuhan kesehatan dasar dan peningkatan status gizi masyarakat melalui puskesmas dimasa yang mendatang dengan semangat kebersamaan dan keterpaduan sesui dengsn fungsi masing-masing dampaknya terlihat pada menurunya status gizi dan kesehatan masyarakat kelompok rentan, yakni bayi, anak balita, ibu hamil, dan menyusui. Sebagian besar pusat kesehatan masyarakat (puskesmas) didaerah pedesaan tidak berfungsi secara optimal karena minimnya dana operasional. Puskesmas ini dititikberatkan pada strategi pendekatan upaya kesehatan bersumber daya masyarakat dengan akses pada modal sosial budaya masyarakat yang didasarkan atas nilai-nilai tradisi gotong royong yang telah mengakar didalam kehidupan masyarakat menuju kemandirian dan keswadayaan masyarakat.

Untuk mencapai tujuan-tujuan pembangunan khususnya dibidang kesehatan kenyataannya sering dihadapkan pada sejumlah kendala seperti pengetahuan, sikap, kesadaran, dan kebiasaan serta kemampuan keuangan dari masyarakat. Hal ini berarti menimbulkan terjadinya kesenjangan antara apa yang menjadi harapan dan kenyataan. Kesemuanya itu akan membawa pengaruh terhadap kesehatan masyarakat. Sekarang ini kualitas sumberdaya manusia Indonesia masih berada pada tingkat yang masih tergolong rendah apabilah dibandingkan dengan Negara-negara tetangga, seperti Malaysia dan singapura. Sejalan dengan hal tersebut maka kesehatan harus selalu diusahakan oleh setiap pribadi, keluarga, dan masyarakat sehingga pada saatnya mereka dapat hidup layak dari sisi kesehatan. Dapat dilihat dari beberapa sisi, misalnya pendidikan dan kesehatan. Dari produktivitas individu yang rendah akan berimplikasi pada rendahnya produktivitas bangsa. Untuk mengatasi permasalahan tersebut maka diperlukan adanya upaya yang nyata dan realistis salah satunya adalah melalui pembangunan dibidang kesehatan dengan melibatkan peran aktif masyarakat dan lembaga-lembaga kemasyarakatan yang ada.

Pembangunan kesehatan adalah bagian integral dari program pembangunan secara keseluruhan. Jika dilihat dari kepentingan masyarakat, pembangunan kesehatan masyarakat desa merupakan kegiatan swadaya masyarakat yang bertujuan meningkatkan kualitas kesehatan 
masyarakat melalui perbaikan status kesehatan dan gizi. Jika dilihat dari kepentingan pemerintah, maka pembangunan kesehatan masyarakat desa merupakan usaha memperluas jangkauan layanan kesehatan baik oleh pemerintah maupun swasta dengan peran aktif dari masyarakat sendiri. Keberhasilan pelaksanaan pembangunan dalam bidang kesehatan sangat tergantung pada peran aktif masyarakat yang bersangkutan. Menyadari akan arti pentingnya peran masyarakat dalam menunjang keberhasilan pembangunan dalam bidang kesehatan diperlukan adanya agen-agen pembangunan yang dapat menumbuhkan kesadaran masyarakat untuk berpartisipasi dalam pembangunan.

Pembangunan dalam bidang kesehatan pada lingkup yang terkecil yaitu Puskesmas (Pusat Kesehatan Masyarakat). Puskesmas yang ada dibangun dan tersebar diseluruh Indonesia. Salah satu pembangunan Puskesmas yaitu di Kabupaten Sorong. Perkembangan puskesmas di kabupaten sorong yang masih membutuhkan pembenahan sarana prasarana maupun dari sisi tenaga Dokter dan Pegawai di puskesmas yang ada di pedesaan. Melihat begitu pentingnya arti kesehatan, sehingga perlu menjadi sorotan utama pemerintah dalam melaksanakan kegiatan di bidang kesehatan. Kondisi geografis Kabupaten sorong masih sangat luas dan jarak antara satu kampong atau desa dengan kampong atau desa yang lain sangat berjauhan begitu juga dengan jarak ke kota, sehingga pembangunan Puskesmas di masing-masing kampong atau desa di Kabupaten Sorong perlu dilakukan.

Namun pembangunan Puskesmas tidak hanya sekedar membangun dan menyediakan tempat untuk melaksanakan kegiatan bidang kesehatan, melainkan perlu adanya sarana pendukung. Pembangunan kesehatan masyarakat yang telah dilaksanakan oleh pemerintah maupun bersama dengan masyarakat di Puskesmas Makbon perlu adanya perhatian khusus.

Yang menjadi sorotan utama peneliti saat turun di lapangan bahwa tiga unsur penting yang harus ada dan terpenuhi yaitu tempat/place, actor/orang, dan activity/aktivitas. Dari ketiga hal tersebut masih sangat kurang. Tempat untuk masyarakat bisa datang dan mengadukan keluhannya mengenai kesehatan masih sangat memprihatinkan dengan kondisi yang tidak memadai dan tidak terawat, kedua actor atau orang-orang yang melaksanakan pelayanan di bidang kesehatan atau dengan kata lain tenaga medis, masih sangat kurang dari segi jumlah, sehingga pelayanan kesehatan tidak berjalan dengan baik, ketiga activity/aktivitas yaitu kegiatan yang ada di tempat tersebut, jika tempat tidak memadai, tenaga medis juga tidak mencukupi hal 
ini akan sangat berdampak bagi kegiatan atau aktivitas pelayanan yaitu pelayanan yang juga tidak maksimal. Selain ketiga hal utama tersebut, masih terdapat juga masalah lainnya yaitu rumah dinas yang tidak layak tinggal, transportasi darat seperti mobi dinas (ambulans keliling), dan kendala dalam pelayan puskesmas keliling (pusling) ke kampung-kampung yang harus menyeberangi laut dengan menggunakan perahu jika angin, dan ombak maka pelayan kesehatan harus ditiadakan mengakibatkan banyak masyarakat yang tidak mendapatkan pelayanan kesehatan dengan baik.

Bertitik tolak dari hal tersebut diatas maka penulis tertarik untuk mengadakan penelitian dengan judul "Analisis Kinerja Pemerintah Daerah (Pegawai Puskesmas) dalam Pelayanan Kesehatan Masyarakat Di Puskesmas Makbon, Distrik Makbon, Kabupaten Sorong." Berdasarkan latar belakang masalah diatas, maka dapat diidentifikasikan beberapa masalah berikut ini.

Tujuan penelitian yang hendak dicapai dalam penelitian ini adalah sebagai berikut.

1. Mendiskripsiskan peran program puskesmas yang telah dilakukan oleh parah pegawai puskesmas dalam meningkatkan kualitas kesehatan masyarakat Distrik Makbon

2. Menjelaskan penyelenggaraan urusan pegawai puskesmas.

\section{TELAAH LITERATUR}

\section{Kinerja}

Menurut Rivai (2006:309-310), kinerja adalah hasil kerja konkret yang dapat diamati dan dapat diukur. Penilaian kinerja mengacu pada suatu sistem formal dan terstruktur yang digunakan untuk mengukur, menilai dan mempengaruhi sifat-sifat yang berkaitan dengan pekerjaan, perilaku dan hasil, termasuk tingkat ketidakhadiran.

Menurut Achmad S. Ruky (2008:14) dalam The Webster Dictionary memberikan tiga arti kata performance, yaitu: (1) Kinerja adalah prestasi yang digunakan dalam konteks atau kalimat misalnya, tentang mobil yang sangat cepat (high performance cars), (2) Kinerja adalah pertunjukan yang biasanya digunakan dalam kalimat folk dance performance atau pertunjukan tarian-tarian rakyat, (3) Kinerja adalah pelaksanaan tugas misalnya dalam kalimat dalam performance his duties. 
Marthis dan Jackson (2006:65) menyatakan bahwa kinerja pada dasarnya adalah apa yang dilakukan atau tidak dilakukan pegawai. Manajemen kinerja adalah keseluruhan kegiatan yang dilakukan untuk meningkatkan kinerja perusahaan atau organisasi, termasuk kinerja masing-masing individu dan kelompok kerja diperusahaan tersebut. Kinerja merupakan hasil kerja dari tingkah laku (Amstrong, 1999:15).

Pengertian kinerja ini mengaitkan antara hasil kerja dan tingkah laku. Sebagai tingkah laku, kinerja merupakan aktifitas manusia yang diarahkan pada pelaksanaan tugas organisasi yang dibebankan kepadanya. Indikator kinerja atau performance indicators kadang-kadang dipergunakan secara bergantian dengan ukuran kinerja (performance measure), tetapi banyak juga yang membedakannya. Pengukuran kinerja berkaitan dengan hasil yang didapat dikuantitatifkan dan mengusahakan data setelah kejadian. Menurut Bernadin dalam Robbins, (2006) indikator kinerja adalah: 1. Kualitas Kerja, 2. Kuantitas, 3. Ketepatan Waktu, 4. Efektifitas, 5. Kemandirian.

\section{Pemerintah Daerah}

Pemerintah daerah merupakan salah satu alat dalam sistem penyelenggaraan pemerintahan. Pemerintah daerah ini merujuk pada otoritas atministratif di suatu daerah yang lebih kecil dari sebuah Negara dimana Negara Indonesia merupakan sebuah Negara yang wilayahnya terbagi atas daerah-daerah provinsi. Daerah provinsi itu dibagi lagi atas daerah kabupaten dan daerah kota. Setiap daerah propinsi, daerah kabupaten, dan daerah kota mempunyai pemerintahaan daerah yang diatur dengan uandang-undang.

Menurut undang-undang Nomor 32 Tahun 2004 Tentang Pemerintah Daerah, pemerintah daerah merupakan kepala daerah sebagai unsur penyelenggara pemerintahaan daerah yang memimpin pelaksanaan urusan pemerintahan yang menjadi kewenangan daerah otonom. Sedangkan pemerintahan daerah adalah penyelenggaraan urusan pemerintahan oleh pemerintah daerah dan dewan perwakilan rakyat daerah menurut asas otonomi dan tugas pembantuan dengan prinsip otonomi seluas-luasnya sebagai mana dimaksut dalam undang-undang dasar Negara republic Indonesia tahun 1945.

\section{Pelayanan Kesehatan Masyarakat}

Pelayanan kesehatan merupakan konsep yang digunakan untuk memberikan layanan secara terus menerus kepada publik dan masyarakat. Pelayanan kesehatan masyarakat (public 
health service) pelayanan dengan cara pengorganisasian yang secara umum dilakukan bersamasama dalam suatu organisasi. Yang bertujuan utama untuk menyembuhkan atau memelihara dan meningkatan kesehatan serta mencegah penyakit, sasaranya yaitu kelompok masyarakat.

Pengertian kesehatan masyarakat menunjukkan pada dua batasan, yaitu: masyarakat itu sendiri dan kesehatan. Istilah masyarakat berasal dari kata community yang dapat diterjemahkan sebagai masyarakat setempat. Dalam masyarakat setempat terdapat beberapa ciri yang selalu melekat, yaitu: seperasaan, sepenanggungan dan saling memerlukan. Individu yang tergabung dalam community merasakan dirinya tergantung pada kelompok yang meliputi kebutuhan fisik maupun kebutuhan psikologinya. Kesehatan masyarakat meliputi bentuk kegiatan atau upaya pencegahan penyakit dan peningkatan kesehatan masyarakat. Kegiatan-kegiatan ini terutama merupakan tanggung jawab masyarakat. Berbicara tentang kesehatan, berarti kita berbicara tentang jiwa raga dan lingkungan dimana manusia itu hidup.

\section{Puskesmas}

Pengertian Puskesmas menurut Trihono dalam buku "Arrimes Manajemen Puskesmas Berbasis Paradigm Sehat" pengertian puskesmas adalah unit pelaksanaan teknis dinas kesehatan kabupaten/kota yang bertanggungjawab menyelenggarakan pembangunan kesehatan disuatu wilayah kerja. Pusat kesehatan masyarakat, disingkat puskesmas, adalah organisasi fungsional yang menyelenggarakan upaya kesehatan yang bersifat menyeluruh, terpadu, merata, dapat diterimah terjangkau oleh masyarakat, dengan peran serta aktif masyarakat dan menggunakan hasil pengembangan ilmu pengrtahuan dan teknologi tepat guna, dengan biaya yang dapat dipikul oleh pemerintah dan masyarakat. Upaya kesehatan tersebut diselenggarakan dengan menitik beratkan kepada pelayanan untuk masyarakat luas guna mencapai derajat kesehatan yang optimal, tanpa mengabaikan mutu pelayanan kepada perorangan.

Pengertian puskesmas yang akan diketengahkan disini menunjukan adanya perubahan yang disesuaikan dengan perkembangan dan tuntutan pelayanan kesehatan dewasa ini, diantaranya adalah:

Menurut dr. Azrul Azwar, MPH (1980) Pusat kesehatan masyarakat (puskesmas) adalah suatu kesatuan oraganisasi fungsional yang langsung memberikan pelayanan secara menyeluruh kepada masyarakat dalam suatu wilayah kerja tertentu dalam bentuk usaha-usaha kesehatan pokok. Menurut Departemen Kesehatan Republik Indonesia (1981). Pusat kesehatan masyarakat 
(puskesmas) adalah suatu kesatuan organisasi kesehatan yang langsung memberikan pelayanan kesehatan secara menyeluruh dan terintegrasi kepada masyarakat diwilayah kerja tertentu dalam usaha-usaha kesehatan pokok.

Puskesmas adalah suatu unit organisasi fungsional yang secara profesional melakukan upaya pelayanan kesehatan pokok yang menggunakan peran serta masyarakat secara aktif untuk dapat memberikan pelayanan secara menyeluruh dan terpadu kepada masyarakat di wilayah kerjanya. Pusat kesehatan masyarakat (puskesmas) adalah salah satu sarana pelayanan kesehatan masyarakat yang amat penting di Indonesia. Puskesmas adalah unit pelaksana teknis dinas kabupaten/kota yang bertanggungjawab menyelangarakan pembangunan kesehatan disuatu wilayah kerjanya.

\section{METOGOLOGI PENELITIAN}

Jenis penelitian yang digunakan dalam penelitian ini adalah termasuk ke dalam penelitian deskriptif; berdasarkan manfaat penelitian termasuk penelitian murni; dan berdasarkan dimensi waktu tergolong dalam penelitian cross sectional. Metodologi yang digunakan dalam penelitian ini adalah metode kualtitatif yaitu studi lapangan (field research) dan studi kepustakaan (library research). Analisis data yang digunakan dimulai dengan mengolah dan mempersiapkan datadata yang diperoleh, baik melalui studi lapangan, maupun studi kepustakaan untuk dianalisis. Data yang diperoleh dari informan yang dilakukan melalui kuesioner dan wawancara mendalam dibuat dalam bentuk transkripsi wawancara (Creswell, 2010: 286).

\section{HASIL DAN PEMBAHASAN}

\section{Peran Program Puskesmas Dalam Meningkatkan Kualitas Kesehatan Masyarakat}

Keberhasilan suatu pelayanan publik merupakan orientasi dalam paradigma pelayanan publik yang saat ini menjadi sorotan disetiap lini pelaksanaan penyelenggaraan pemerintahan. Untuk mengetahui keberhasilan yang dimaksud bisa diketahui melalui kepuasan yang dirasakan oleh pelanggan akan sangat mempengaruhi kinerja pelayanan publik karena masyarakat merupakan unsur terpenting dalam proses pelayanan yaitu sebagai subjek yang akan memaknai pelayanan yang telah mereka terima.

Kepuasan pasien sebagai pengguna jasa puskesmas akan terpenuhi apabila puskesmas memberikan pelayanan dengan cara meningkatkan kualitas pelayanan atau mengoptimalisasikan 
pelayanan, yaitu melalui peningkatan berbagai kegiatan pelayanan serta berusaha untuk memperbaiki dan sekaligus menambah sarana dan prasarana yang menunjang kinerja untuk memperlancar pemberian pelayanan kesehatan kepada pasien. Pasien sebagai sasaran utama atas jasa pelayanan yang diberikan oleh instansi kesehatan dalam hal ini adalah puskesmas makbon.

1. Hubungan Petugas Medis Dengan Pasien

Hubungan petugas medis dengan pasien cukup baik dalam hal berkomunikasi antara petugas dengan pasien dan lain sebagainya. Namun terkadang ada hal-hal yang menghambat akan hubungan itu seperti keterlambatan dalam pelayanan yang diakibatkan dengan letak wilayah pelayanan kesehatan dengan kekuasaan puskesmas makbon yang begitu jauh dari kampung-kampung yang satu ke kampung-kampung yang lain. Sehingga hubungan antara petugas medis dengan pasien menjadi kurang baik. Oleh karena itu ada beberapa poin-pon penting dari hasil wawancara antara peneliti dengan beberapa pegawai puskesmas makbon dan pasien diwilayah distrik makbon sebagai berikut.

\section{a. Harapan Pasien}

Dalam pelayanan kesehatan sangatlah penting adanya kompetensi teknis dari pegawai puskesmas atau pemberi layanan, sehingga setiap pasien dapat ditangani secara baik dan profesional. Kompetensi pegawai terkait dengan kemampuan pegawai dalam menangani pasien yang meliputi beberapa hal yaitu :

a. Petugas yang selalu siap melayani pasien

b. Pelayanan yang dilakukan kepada pasien sesuai prosedur yang berlaku

c. Memberikan pelayanan secara profesional

Kompetensi pegawai puskesmas bisa diketahui dari beberapa wawancara pasien tentang keterampilan puskesmas yaitu sumber dari wawancara pasien.

“..bapak pernah sakit yang tidak bisa di bawah lagi ke puskesmas, waktu itu bapak sudah dirawar di rumah sakit umum kabupaten sorong bapak disuruh mengurus surat keterangan dari puskesmas bapak suruh anak-anak bapak pergi urus ke puskesmas tidak ada dokter terpaksa mereka harus cari dokter ke rumah dokter itu lagi.." Nama narasumber : Bpk.Ferdinan (sabtu, 6 oktober 2018)

Hasil wawancara dari narasumber menjelaskan bahwa kepada petugas medisdipuskesmas makbon harus berada di tempat kerja setiap waktu agar pasien mendapat pelayan seperti petugas 
puskesmas di daerah-daerah perkotaan (puskesmas remu atau puskesmas sekitarnya) yang petugasnya selalu siap ditempat dan tepat pada waktu pelayanan.

\section{b. Kenyataan Dilapangan}

Untuk terpenuhinya petugas agar berhasil dalam memberikan pelayanan dipengaruhi oleh kendala-kendala yang menghabat pelayanan dipuskesmas makbon. Kendala-kendala tersebut berupa sarana dan prasana seperti: perumahan petugas medis, mobil puskesmas keliling, transportasi laut yang akan menjadi acuan para pegawai puskesmas dalam bertugas melayani pasien. Hal ini sebagai ungkapan oleh salah satu pegawai puskesmas makbon.

"iya ada banyak kendala yang saya dengan teman-teman rasakan setiap jam kerja dan kalau waktu kita turung ke kampung-kampung untuk pelayanan yang menjadi kendala itu transportasi darat dan laut hal-hal itu yang menjadi kendala untuk kita pegawai puskesmas." Nama narasumber : Antoneta Emauri (senin 1 oktober 2018).

Keadaan sarana dan prasarana yang menjadi acuan para pegawai puskesmas dalam memberikan pelayanan belum banyak diketahui oleh masyarakat. Kendala ini juga menjadi perhatian utama atau pelayanan yang diberikan puskesmas. Sesuai dengan penjelasan yang disampaikan oleh pegawai puskesmas di atas hal ini dikemukakan juga oleh salah satu pegawai puskesmas.

"Di puskesmas ini setiap hari dijaga oleh 2 dokter umum.Masing - masing punya tugas sendiri-sendiri dihari yang berbeda biasanya 1 tugas hari senin yang satunya hari selasa.Hal ini dikarenankan perumahan pegawai yang kurang memadai." Nama narasumber : bpk.melkianus Paa (senin 01 oktober 2018)

Berdasarkan keterlambatan dalam pelayanan ini juga diakibatkan dengan adanya kendala berupa perumahan yang dialami oleh pegawai puskesmas makbon. Selain itu untuk meningkatkan kemampuan teknis dari para petugas kesehatan juga dilakukan kegiatan berupa pelatihan-pelatihan yang di ikuti oleh dokter sampai petugas yang levelnya paling bawah. Hal ini di ungkapkan oleh kepala puskesmas :

“jadi kami dari pihak puskesmas untuk meningkatkan kualitas pelayanan pegawai saya selaku kepala puskesmas menyuruh anak-anak buah saya untuk mengikuti pelatihanpelatihan agar mereka mendapatkan pengalaman-pengalaman baru." Nama narasumber: Bpk. Ferdinan Kilala (Rabu 3 oktober 2018) 
Pihak puskesmas juga sering mengikutsertakan para petugasnya baik perawat atau dokter maupun bagian lainya untuk mengikuti kegiatan pelatihan yang biasanya diadakan dengan melakukan kerjasama dengan pihak lainya.

\section{c. Kepuasan Pasien}

Kepuasan pasien kepada pelayanan kesehatan oleh pegawai puskesmas makbon berdasarkan hasil pengamatan yang dilalukan oleh seorang pasien sebagai berikut.

"ooh iya kalau saya lihat penanganan pasien disini baik, dokter dan petugas lainya juga baik-baik saja, melayaninya, juga cepat. ’Sumber :ibu.Dormina (selasa 02 oktober 2018)

Berdasarkan yang telah dialami oleh pasien menyebutkan bahwa kemampuan para dokter dalam menangani pasien maupun pegawai lainnya berdasarkan apa yang terjadi di puskesmas makbon dirasakan sudah cukup baik oleh pasien sekalipun dari segi jumlah sangat kurang.

Selain itu juga di ungkapkan oleh pasien lainya sebagai berikut :

"Sekarang disini torang sudah merasakan pelayanan puskesmas lebih baik daritahuntahun yang lalu, sekarang petugas dorang kerja sudah bagus hal ini harus di pertahankan, biar masyarakat senang datang dan berobat disini lebih banyak lagi.’Sumber :ibu.Naomi (rabu 10 oktober 2018).

Jadi berdasarkan berbagai kendala diatas tersebut tidak menghalangi mereka untuk terus bekerja hal itu menunjukan dan mengarah bahwa kemampuan serta keterampilan para pegawai yang terdiri dari para perawat, dokter dan petugas medis lainya dirasakan sudah cukup baik, namun belum semua pegawai atau tenaga medis yang melakukan pelayanan.

2. Penyelenggaraan Kegiatan Pegawai Puskesmas Makbon

Puskesmas keliling ke kampung-kampung. Penyelenggaraan kegiatan pegawai puskesmas yang sering disebut dengan puskesmas keliling (Pusling) ini dilakukan rutin setiap bulan setiap minggu kedua pada tanggal 12 sampai dengan minggu terakhir tanggal 25 kesetiap kampung-kampung yang ada dalam wilayah kekuasaan puskesmas makbon. Puskesmas keliling (Pusling) didistrik makbon menurut tingkat perkembanganya, puskesmas ini dapat dikategorikan kedalam puskesmas keliling (pusling), dimana puskesmas keliling (pusling) ini sudah menjadi kegiatan rutin setiap bulan.

Hasil wawancara mengenai penyelenggaraan puskesmas keliling (pusling) yang rutin dilakukan setiap bulan dapat dilihat dari hasil wawancara yang dilakukan langsung oleh peneliti dengan seorang ibu di kampung malaumkarta. 
"yang mama tau itu setiap bulan di kampung malaumkarta ini pelayanan puskesmas keliling itu setiap tanggal 15, dan pelayanan yang mama dong terima disini rutin setiap bulan yaitu pemeriksaan ibu hamil, pemberian vitamin bagi balita, dan ada suntik campak buat anak-anak bayi balita. Anak-anak disini kadang-kadang itu ada prongram baru yang harus dilaksanakan pada saat puskesmas keliling (pusling) tersebut seperti yang mama dong terima yaitu pelayanan bulan eliminasi kaki gaja (belkaga) setiap bulan oktober, terus adalagi seperti periksa malaria dan lain-lain itu saja anak yang mama tau." Narasumber :ibu. Bethiana kalami (senin,15,oktober 2018)

Dapat dilihat bahwa penyelenggaraan puskesmas keliling (pusling) ke kampungkampung dapat di terima oleh masyarakat dengan baik dan pelayanan kesehatan kepada masyarakat juga di rasakan oleh masyarakat melalui pelayanan puskesmas keliling (pusling) ke kampung-kampung yang berada di wilayah kekuasaan puskesmas makbon. Penyelenggaraan pegawai puskesmas dapat diketahui dari beberapa wawancara pegawai puskesmas tentang pelaksanaan puskesmas keliling ke kampung-kampung oleh seorang pegawai.

"iya anak dulu bapak dong kalau melakukan pelayanan puskesmas keliling (pusling) ke kampung-kampung itu tidak sama dengan sekarang yang jalan sudah sampai di kampung-kampung yang berada jauh dari daerah perkotaan." Sumber : bpk.Melkianus.Paa (senin 01 oktober 2018)

Selain itu juga diungkapkan oleh pegawai puskesmas sama :

"waktu dulu itu bapak dengan teman-teman jalan kaki naik turung gunung, dan menyeberangi laut dari kampung ke kampung yang lain demi pelayanan kesehatan kepada masyarakat.’Sumber : bpk.M.Paa (senin,01 oktober 2018)

Pelaksanaan pelayanan puskesmas keliling ke kampung-kampung telah dirasakan adanya perubahan yang lebih baik dibandingkan dengan tahun-tahun lalu yang mana jalan yang yang menjadi halangan bagi pegawai puskesmas makbon. Kondisi jalan pada waktu itu belum adanya pembangunan jalan dari kota ke kampung-kampung di daerah terpencil, namun sekarang petugas medis dengan masyarakat sudah menikmati pembangunan jalan dari kota sampai ke kampungkampung dengan baik.

Pelaksanaan Program Yang Di Lakukan Dilapangan. Pelayanan kesehatan kepada masyarakat adapun program dan tujuan yang ingin dicapai oleh pegawai puskesmas kepada masyarakat agar masyarakat dapat hidup sehat dan sejahtera. Berikut ini adalah mengenai program puskesmas yang terkait dengan: 
1. Penimbangan (balita, dewasa)

2. Pemberian makanan tambahan

3. Pemeriksaan tensi

4. Pendataan ibu hamil

Adapun program-progarm puskesmas yang terkait dengan pelayanan kesehatan kepada masyarakat telah terlaksanakan dengan baik ada juga yang tidak terlaksanakan dengan baik berdasarkan kendala-kendala yang dialami oleh petugas puskesmas.

Hal ini disampaikan oleh seorang pegawai puskesmas makbon:

"ya kalau kita turung pusling ke kampung-kampung itu kita ikut berbagai peraturan yang harus kita jalankan tapi kadang itu tidak kita laksanakan atau kita telat pelayanan itu semua tergantung pada cuaca, dan transportasi."Sumber : pegawai (senin 01 oktober 2018)

Semua perjalanan puskesmas keliling tergantung pada cuaca karena jika cuacanya tidak baik maka semua yang ingin dilaksanakan pada waktu itu tidak dapat berjalan dengan baik. Kegiatan yang dilaksanakan dilapangan setiap bulan pada tanggal yang telah ditentukan sesuai dengan program yang harus dilakukan dapat disampaikan juga oleh seorang pegawai puskesmas sebagai berikut :

"kalau kita turung ke kampung-kampung untuk menjalankan program kesehatan itu berupa tensi bagi pasien, pemeriksaan ibu hamil, suntik campak, dan penimbangan balita. Jika kita menjalankan program itu kita sudah dibantu oleh beberapa kader-kader kampung yang berada dikampung masing-masing.ada juga program yang setiap tahun di bulan oktoberharus kami jalankan kepada masyarakat yaitu penanganan program belkaga (kaki gaja) agar masyarakat terhindar dari penyakit itu. Namun dari setiap program itu ada yang tidak terlaksana berupa transportasi darat dan laut." Narasumber: bpk. M.Paa (senin,1 oktober 2018).

Hal ini disampaikan langsung oleh salah satu masyarakat berkaitan dengan program puskesmas sebagai berikut :

"iya jadi ada banyak program yang harus dilakukan oleh petugas kepada kami masyarakat tapi ada program yang tidak terlaksana seperti program suntik campak kepada anak-anak kami yang balita, hal ini sering terjadi terkadang dilaksanakan dan kadang juga tidak ada pelaksanaan. Sehingga anak-anak kami bawa ke kota untuk suntik campak di kota." Narasumber : ibu.Ruth.M (senin.15 oktober 2018)

Dapat kita lihat dari hasil wawancara dengan seorang kader posyandu di kampung malaumkarta sebagai berikut : 
"kami sebagai kader posyandu yang dapat kami lakukan itu seperti penimbangan balita, dan daftar ibu hamil. Lain dari itu kami tergantung kepada pegawai puskesmas yang melakukan pelayanan puskesmas keliling setiap bulan ke kampung-kampung." Sumber dari : ibu. Meri.Majefat(senin,15 oktober 2018)

Setiap program pelaksanaan yang dilakukan oleh pegawai puskesmas makbon ada berbagai macam program yang harus dilaksanakan kepada masyarakat sesuai dengan prosedur yang harus dijalankan berdasarkan hasil wawancara peneliti dengan masyarakat dan kader posyandu setempat, diwilayah pelayanan puskesmas. Pelaksanaan program puskesmas ini peneliti dapat menemukan ada berbagai macam program yang terlaksana dengan baik dan adapula yang tidak terlaksana dengan baik hal ini semua diakibatkan dengan berbagai kendalakendala yang ditemukan dilapangan berupa transportasi darat dan laut.

Pentingnya program posyandu juga sangatlah penting bagi masyarakat. Selain itu kegiatan lain yang dilakukan oleh puskesmas adalah mendorong masyarakat untuk ikut aktif dalam kegiatan puskesmas. Mengigatkan masyarakat tentang pentingnya posyandu, dan imunisasi buat anak-anaknya. Puskesmas keliling (Pusling) ini biasanya diadakan setiap bulan, minggu ke dua, biasanya kalau tidak disiarkan dari kader-kader setempat dapat disiarkan dari mulut ke mulut.

Adapun 5 program puskesmas yang merupakan sebuah upaya mandiri warga dalam upaya mempermudah pelayanan kesehatan khususnya masyarakat menengah kebawah yang mencakup :

1. Pelayanan keluarga berencana KB

2. Kesehatan ibu dan anak

3. Imunisasi

4. Perbaikan gizi

5. Dan penanggulangan diare

Untuk mengetahui setiap program yang dijalankan oleh seorang petugas medis dapat kita lihat dari hasil wawancara peneliti dengan pegawai puskesmas.

"iya jadi setiap bulan pada tanggal yang sudah kami tentukan untuk melakukan kunjungan kesehatan ke kampung-kampung itu kami selalu turung dengan programprogram kesehatan yang harus kami lakukan kepada masyarakat." Nama narasumber : Antoneta E (Senin 01 oktober 2018) 
Hal ini terlihat pada proses pelayanan kesehatan yang dilakukan oleh puskesmas yang dilaksanakan secara rutin setiap bulan pada minggu kedua yang dilakukan pada pukul 09.00 sampai dengan selesai. Pelaksanaan program puskesmas ini sangat penting bagi kesehatan masyarakat di wilayah pelayanan puskesmas makbon yang mana mencakup beberapa kampung dan dengan berbagai letak georafis yang berbeda-beda sehingga ada banyak halangan dan rintangan yang harus dihadapi oleh petugas medis untuk mencapai kesuksesan dalam menjalankan pelayanan kesehatan kepada masyarakat di wilayah puskesmas makbon.

Berdasarkan analisis diatas dapat dikatakan bahwa pelayanan yang diberikan sudah baik sekalipun jumlah tenaga medis masih sangat kurang. Jumlah tenaga medis yang minim ini dikarenakan rumah atau tempat tinggal tenaga medis yang masih sangat tidak layak untuk ditempati, sehingga mereka lebih memilih untuk tinggal di rumah warga atau jika selesai melaksanakan tugas para petugas atau pegawai kembali ke kota dan untu kembali lagi ke kabupaten makbon memakan waktu yang lama.

Pelayanan dalam bentuk program sudah ditetapkan dan berjalan, namun semua kegiatan pelayanan bergantung pada cuaca, jika cuaca baik maka kegiatan pelayanan dapat dilaksanakan, sedangkan jika cuaca buruk pelayanan akan sulit di laksanakan, hal ini menimbulkan keresahan bagi warga setempat, karena jika cuaca buruk dan perlu penanganan medis maka warga harus melakukan perjalanan ke kota untuk mendapatkan pelayanan kesehatan.

\section{Halangan Dan Rintangan Yang Harus Di Hadapi Oleh Petugas Medis}

Setiap pelayanan yang dilakukan oleh pegawai puskesmas semua berjalan sesuai dengan tujuan puskesmas yang ingin dicapai oleh pegawai terkadang dalam proses pelayanan ke kampung-kampung ada banyak halangan dan rintangan yang harus dihadapi berupa sarana dan prasarana di puskesmas makbon yang kurang lengkap kendala itu berupa perumahan pegawai, transportasi darat dan transportasi laut.

Perumahan puskesmas ini yang menjadi halangan bagi pegawai puskesmas makbon ada banyak pegawai puskesmas yang tinggal bersama dengan keluarga mereka yang berada di distrik makbon dan bahkan ada juga yang memilih untuk kembali lagi ke kota setelah jam kerja. Semua itu diakibatkan dengan minimnya perumahan medis dan rumah tidak layak untuk ditinggal karena rumah sudah lama dan Rusak. Sumber wawancara dari seorang pegawai puskesmas. 
Berdasarkan hasil penelitian ada berbagai macam halangan dan rintangan yang harus dihadapi oleh seorang pegawai puskesmas baik itu perawat, bidang, dan dokter. Hal ini disampaikan langsung oleh seorang pegawai puskesmas makbon. Transportasi ini sangat penting bagi petugas medis dan hal ini juga yang menjadi kendala pelayanan pegawai kesehatan. Sehingga terjadi keterlambatan dalam pelayanan ke kampung-kampung yang harus melewati lautan dan mendaki gunung dari kampung satu ke kampung yang lain dengan letak geografi yang berbeda-beda. Pelayanan kepada masyarakat itu sangat penting harus di perhatikan juga oleh pemerintah daerah dalam hal pelayanan kesehatan kepada masyarakat terutama transportasi darat dan laut.

\section{SIMPULAN DAN SARAN}

\section{Simpulan}

Puskesmas makbon telah berusaha memberikan pelayanan kesehatan dengan baik. Namun jika ditinjau dari tiga unsur utama dalam pelayanan publik yaitu tempat/place, orang/actor, dan kegiatan/activity, masih sangat kurang. Pertama tempat yaitu tersedianya lahan dan ruang untuk melakukan pelayanan kesehatan kepada masyarakat atau dengan kata lain telah tersedia puskesmas Makbon namun tempat atau ruang pendukung bagi tenaga medis masih sangat minim atau tidak layak huni. Kedua, orang/actor, dengan kondisi tempat tinggal bagi tenaga medis yang tidak layak huni sehingga tenaga medis atau pegawai (sebagian besar) terkadang tidak berada di tempat saat pelayanan kesehatan di lakukan, hanya sebagian kecil tenaga medis atau pegawai yang ada yang melakukan pelayanan hal tersebut dikarenakan mereka merupakan warga setempat dan memiliki rumah pribadi atau tinggal bersama keluarga di Makbon. Ketiga, activity atau kegiatan, dengan jumlah tenaga medis dan pegawai yang sangat minim sehingga pelayanan yang diberikan juga tidak semaksimal jika dibandingkan dengan memiliki tenaga medis atau pegawai yang banyak. Penempatan pegawai dan tenaga medis di masing-masing puskesmas sudah ditetapkan berdasarkan jumlah masyarakat yang ada, sehingga jika tenaga medis atau pegawai kesehatan tidak melakukan tugasnya di tempat di mana mereka di tempatkan salah satunya di makbon, maka pelayananpun akan kurang maksimal.

a. Peran Program Puskesmas Dalam Meningkatkan Kualitas Kesehatan Masyarakat

Peran program puskesmas dalam meningkatkan kualitas pelayanan kesehatan kepada masyarakat yang dilakukan oleh pegawai puskesmas makbon sudah cukup baik, peran 
puskesmas ini ditunjukan dengan adanya dokter dan pegawai puskesmas makbon dalam menangani pasien, penanganan pasien yang sesuai dengan prosedur yang berlaku, dan selalu mengedepankan profesionallitas dalam memberikan pelayanan kepada pasien/masyarakat, namun kekurangannya adalah jumlah tenaga medis dan pegawai yang kurang sehingga pelayanan yang diberikan juga tidak begitu maksimal.

b. Penyelenggaraan Kegiatan Pegawai Puskesmas Makbon.

Dalam penyelenggaraan pelayanan kesehatan kepada pasien dipuskesmas makbon cukup baik, hal ini ditunjukan dengan adanya program puskesmas keliling ke kampung-kampung (Pusling), dan 4 program lainnya yang dilaksanakan adalah: penimbangan balita, dewasa, pemberian makanan tambahan, pemeriksaan tensi, pendataan ibu hamil. Namun masih ditemukan adanya kendala-kendala yang dialami oleh pegawai puskesmas dalam mengakses atau menjangkau layanan kesehatan di wilayah puskesmas makbon yang terhalang dari segi geografis, dan sarana prasarana yang kurang memadai.

\section{Saran}

Berdasarkan hasil kesimpulan mengenai kinerja pemerintah daerah pegawai puskesmas dalam pelayanan kesehatan masyarakat dipuskesmas makbon maka peneliti memberikan saran sebagai masukan dan bahan pertimbangan bagi pihak yang terkait sebagai berikut:

a. Untuk meningkatkan kualitas program pelayanan kesehatan pegawai puskesmas makbon kepada masyarakat perlu dilakukan perubahan dan penambahan fasilitas yang diberikan kepada masyarakat atau pasien dalam melakukan proses administrasi di puskesmas makbon.

b. Perlu adanya perhatian dari pemerintah daerah dalam hal pembangunan perumahan dan diberikan bantuan berupa kendaraan transportasi darat dan laut bagi pegawai puskesmas makbon, untuk meningkatkan pelayanan kesehatan kepada masyarakat oleh para petugas yang ada agar tugas yang diberikan dapat dilaksanakan dengan baik tanpa ada kendalakendala yang dialami dan dapat melayani masyarakat dengan baik pula.

c. Perlu adanya tindakan tegas kepada tenaga medis atau pegawai yang mangkir dari tugas yang telah diberikan kepadanya sesuai penempatan tempat tugas, sehingga tenaga medis atau pegawai yang mangkir tersebut dapat di gantikan atau dipindahtugaskan agar pelayanan kesehatan di Kabupaten (kampong dan desa) dapat berjalan dengan baik dan 
sesuai peraturan kesehatan pada umumnya. Karena kesehata merupakan hal yang sangat penting. Jumah tenaga medis dan pegawai yang telah ditetapkan sudah disesuaikan dengan jumlah masyarakat yang perlu dilayani, sehingga jika ad apegawai atau tenaga medis yang mangkir, maka akan terjadi kepincangan pelayanan.

\section{DAFTAR PUSTAKA}

Achmad, S. Rucky.2008. Manajemen Sumber Daya Manusia.Jakarta: Bumi Aksara.

Amstrong, Mischael, 1999. Manajemen Sumber Daya Manusia. Terjemahan Sofyan dan Haryanto. PT. Elex Media Komputindo. Jakarta.

Azwar, Azrul. 1980. Pukesmas dan Usaha Kesehatan Pokok . Jakarta Pusat: CV. Akadoma.

Azwar, Azrul. 1983. Pukesmas dan Usaha Kesehatan Pokok Edisi 2. Jakarta Pusat: CV. Akadoma.

Creswell, John W. (2010). Research Design: Pendekatan Kualitatif, Kuantitatif, dan Mixed. Yogyakarta: Pustaka Pelajar.

Dainur. 1992. Materi-materi Pokok Ilmu Kesehatan Masyarakat. Cetakan Pertama. Penerbit Widya Medika. Jakarta.

Depkes RI.(1992), Pembangunan KesehatanMasyarakat. Mathis dan Jackson (2006:65).

Mathis, R.L. \& J.H. Jackson. 2006. Human Resource Management: Manajemen Sumber Daya Manusia. Terjemahan Dian Angelia. Jakarta: Salemba Empat.

Nasrul Effendy.(1998).Dasar-dasar kesehatan masyarakat.Jakarta:Penerbit Buku Kedokteran EGC

Nasution, S. 1988. Metode Penelitian Naturalistik Kualitatif. Tarsito.BandungTarsito.

Natsir M,1998, Metode Penelitian (Jakarta: Ghalia Indonesia).

Rivai, Veithzal.2006. Manajemen Sumber Daya Manusia Untuk Perusahaan.Jakarta: Raja Grafindo Persada.

Robbins, P. Stephen. (2006). Perilaku Organisasi. Edisi Sepuluh. Diterjemahkan oleh: Drs. Benyamin Molan. Erlangga, Jakarta.

Trihono. 2005. Manajemen Puskesmas Berbasis Paradigma Sehat. Jakarta: CV Sagung Seto.

Undang-UndangNo.23 ( 2004) tentang FungsiPerintah Daerah.

Undang-UndangNomor23 (2014) tentangPemerintah Daerah.

Undang-Undang No.9 (1992) TentangPokok-pokok Kesehatan.

Departemen Kesehatan Republik Indonesia (1981). 